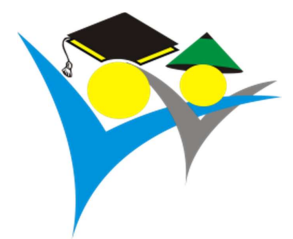

\title{
Pengelolaan Organisme Pengganggu Tanaman (OPT) Pada Tanaman Kedelai Di Desa Puyung
}

\author{
Mulat Isnaini $^{1 *}$, Hermah Suheri ${ }^{2}$, Hery Haryanto ${ }^{1}$, Irwan Muthahanas ${ }^{1}$ \\ ${ }^{1}$ (Program Studi Hama dan Penyakit Tanaman, Fakultas Pertanian Universitas Mataram, Mataram - Indonesia; \\ ${ }^{2}$ (Program Studi Agroekoteknologi, Fakultas Pertanian Universitas Mataram, Mataram - Indonesia.
}

Article history

Received: 6 Desember 2021

Revised: 8 Desember 2021

Accepted: 21 Desember 2021

*Corresponding Author:

Mulat Isnaini,

Program Studi Hama dan Penyakit

Tanaman, Fakultas Pertanian

Universitas Mataram, Mataram -

Indonesia.

Email:mulat@unram.ac.id

\begin{abstract}
This extension activities were conducted at Puyung village Jonggat, Central Lombok. The activity was addressed to farmer group who usually grow 'palawija', corn and paddy rice. Famers very often faced some difficulties with insect pest which attacked soybean from stage of vegetatif to generative. Usually, famers control those pests by spraying insecticide, however, they do not realize that applying insecticides for long period of time causing resurgence for insect, beneficial organisms such as predator also were killed and also causing generous for environment. Hence, its new innovation such as planting refugia plants with different kind of flowers were able to take over control those insects as predators trapping. Methods were used survey by using descriptive explorative continued with action research, approached participatory action program, from farmer group via discussion, and worked together in the group. Steps of those activities started with training, talk and discussion proportionally with $30 \%$ for theory and $70 \%$ for field action. The other step was to do demonstration plot in the field by planting refugia plants such as sunflower, marigold etc. surrounding soybean plantation from August to November 2021. The results showed that: a) knowledge and skills of member of the group was increasingly to control insect; $b$ ) the famers eager to do planting refugia plants as trapping predators around soybean plantation; c) create the formation of technology package in controlling insect by planting refugia plants used as trapping predator or natural enemy for insects.
\end{abstract}

Keywords: demonstration plot; green soybean; refugee crops

Abstrak: Pelaksanaan kegiatan pengabdian kepada masyarakat dilakukan di desa Puyung kecamatan Jonggat, Lombok Tengah. Kelompok sasaran adalah kelompok tani yang terbiasa menanam tanaman palawija, jagung dan padi. Kendala yang sering dialami oleh petani tersebut adalah serangan hama pada tanaman kedelai sejak fase vegetatif sampai generatif. Biasanya petani menyemprot dengan pestisida sehingga tidak disadari lama kelamaan akan menyebabkan serangga hama menjadi tahan dan merusak lingkungan. Selain itu, pestisida yang diaplikasi secara terus menerus dapat mengakibatkan matinya organisme bukan sasaran termasuk predator. Sehingga perlu dilakukan inovasi baru untuk mengendalikan hama selain menggunakan bahan kimia yang tidak ramah lingkungan. Inovasi baru yang dimaksud adalah menanam tanaman refugia sebagai perangkap musuh alami hama. Metode yang dilakukan adalah teknik survei dengan metode deskriptif eksploratif dilanjutkan dengan kaji tindak (Action Research) dengan menerapkan pendekatan program tindak partisipatif (Partisipatory Action Program) dari anggota kelompok tani melalui diskusi, dan kerja kelompok di seluruh kegiatan. Selanjutnya tahapan pelaksanaan yang diawali dengan pelatihan dengan teknik ceramah dan diskusi, dengan proporsi $30 \%$ teori dan $70 \%$ praktek lapang. Sebagai tindak lanjut dari kegiatan tersebut adalah dilakukan demonstrasi plot dengan menanam tanaman refugia seperti bunga matahari, kenikir, bunga kertas, di sekitar tanaman kedelai dari bulan Agustus sampai dengan bulan November 2021. Hasilnya kegiatan ini dapat disimpulkan bahwa, a) pengetahuan dan keterampilan anggota Kelompok tani meningkat dalam kaitannya dengan pengendalian hama, b) Kelompok tani mau menerapkan tanaman refugia sebagai perangkap musuh alami hama pada tanaman kedelai, c) terbentuknya paket teknologi tentang teknik pengendalian hama dengan memanfaatkan tanaman refugia sebagai tanaman perangkap musuh alami hama.

Kata kunci: petak demonstrasi; kedelai sayur; refugia 


\section{PENDAHULUAN}

Serangan hama menyebabkan penurunan hasil dan kualitas biji sehingga menyebabkan stok biji yang akan ditanam kualitasnya menurun. Sebagian besar hama dan penyakit secara langsung berakibat pada biji kedelai yang ditanaman atau sebagai konsumsi untuk langsung dimakan. Hama dan penyakit yang menyebabkan penurunan kualitas biji karena serangan pada sebagian tanaman kedelai menyebabkan terbatasnya hara untuk perkembangan biji yang dihasilkan dan memperpendek umur tanaman. Beberapa hama yang menimbulkan kerusakan pada tanaman kedelai adalah ulat yang menyerang biji dengan gejala biji berwarna pucat kekuningan, larva membuat gerekan pada biji yang sedang berkecambah dan pada biji di dalam tanah. Kerusakan yang ditimbulkan menyebabkan pertumbuhan daun dan akar tanaman menjadi abnormal. Selain ulat, aphid menghisap cairan dari tanaman kemudian mengeluarkan senyawa yang lengket yang disebut honey dew atau tetes madu yang dapat mengurangi proses fotosintesis karena masuknya sinar matahari terhalangi. Aphid juga merupakan vektor virus mosaik. Apabila keberadaan aphid sangat banyak maka menurunkan vigor tanaman, laju pertumbuhan, menurunkan terbentuknya polong sehingga menurunkan hasil (Rutledge et al., 2004). Di tanah pertanian khususnya Indonesia, polusi tanah, erosi, hara yang tidak seimbang, pemupukan yang berlebihan mengakibatkan penurunan kesehatan tanah (Bohlool et al., 1992).

Usaha pemulihan kondisi tersebut paling tidak harus ada keseimbangan di lingkungan ekosistem yaitu pemberian nutrisi tanaman yang dirasa sangat penting dilakukan untuk pertumbuhan dan peningkatan hasil. Salah satu teknik melalui rekayasa ekologi, yaitu desain sebuah sistem pertanian berkelanjutan (Kangas, 2005). Salah satu contoh rekayasa ekologi tersebut adalah menanam tanaman refugia di sekitar areal tanaman yang dibudidayakan.

Pengendalian hama dengan cara bercocok tanam seperti pemanfaatan tanaman pinggir atau ada yang menyebutnya dengan tanaman perangkap, dapat mendorong stabilitas ekosistem sehingga populasi hama dapat ditekan dan berada dalam keseimbangannya, atau secara tidak langsung ikut berperan dalam mendorong konservasi musuh alami seperti predator dan parasitoid. Jenis tanaman pinggir yang dipilih harus mempunyai fungsi ganda yaitu, di samping sebagai penghalang masuknya hama ke pertanaman pokok, tanaman refugia juga berfungsi untuk berlindung sementara dan penyedia tepung sari untuk makanan alternatif predator dan parasitoid, jika mangsa utama populasinya rendah atau tidak ada di pertanaman pokok (Mahmud, 2006). Tanaman refugia adalah tumbuhan (baik tanaman maupun gulma) yang tumbuh di sekitar tanaman yang dibudidayakan, yang berpotensi sebagai mikrohabitat bagi musuh alami hama. Bagi musuh alami, tanaman refugia ini memiliki banyak manfaat di antaranya adalah sebagai sumber nektar bagi musuh alami sebelum adanya populasi hama di pertanaman. Suatu rekayasa ekologi dengan menanam tanaman refugia maka konservasi musuh alami dapat terus terjaga.

\section{METODE}

Teknik yang diterapkan di lingkungan desa Puyung merupakan salah satu solusi tidak hanya melindungi tanaman dari serangan hama tetapi juga serangan patogen penyebab penyakit khususnya patogen tular tanah. Dengan demikian teknik yang akan ditawarkan tidak berdampak negatif terhadap lingkungan. Upaya yang dilakukan meliputi beberapa tahapan yaitu:

1. Melakukan observasi lapang dengan teknik wawancara langsung tentang masalah-masalah riil yang dihadapi oleh kelompok tani.

2. Setelah diketahui permasalahan yang dihadapi, maka dilakukan pelatihan atau pendidikan dengan cara field day beberapa kali untuk mencari jalan keluarnya dengan tujuan untuk menanamkan pengetahuan, kemampuan dan kemauan agar anggota kelompok tani lebih mudah dalam mengatasi permasalahannya.

3. Langkah selanjutnya dari pelatihan, segera dilakukan demonstrasi plot (demplot) berupa action research dengan melibatkan secara langsung petani atau kelompok tani dari awal sampai selesainya kegiatan.

4. Untuk mengetahui berhasil atau tidaknya semua kegiatan yang dilakukan, maka dilakukan evaluasi sesuai dengan tahapan kegiatan. 


\section{HASIL DAN PEMBAHASAN}

Tahapan-tahapan kegiatan pengabdian seperti terlihat pada gambar-gambar berikut. Kegiatan yang diawali dengan survey ke lokasi dilanjutkan dengan identifikasi masalah. Hasil survey di Desa Puyung menunjukkan bahwa pertanaman kedelai banyak rusak karena serangan hama.

Untuk menindak lanjuti hasil survey, maka tim dari Fakultas Pertanian melakukan wawancara dengan ketua mitra kelompok tani maka kegiatan dilanjutkan dengan penyuluhan dan pendampingan.

Selanjutnya diadakan diskusi dan sebagai akhir setelah diskusi dilakukan langkah akhir sebagai kaji tindak adalah demonstrasi plot (demplot) yaitu penanaman tanaman refugia disekitar tanaman budidaya dan dilanjutkan dengan penanaman kedelai. Sebagai langkah awal persiapan, tanah dicangkul untuk membersihkan batu-batu dan gulma kemudian ditugal dan biji kedelai ditanam dengan jarak 20 x $40 \mathrm{~cm}$.

Dari hasil demplot terlihat beberapa jenis serangga yang tertangkap pada perekat warna kuning diamati baik yang ditancapkan di pertanaman refugia maupun di pertanaman kedelai (Gambar 1). Beberapa contoh tanaman refugia yang ditampilkan adalah yang dibudidayakan maupun yang memang secara khusus didatangkan dari luar, seperti bunga Merigold (Tagetes erecta L), bunga Matahari (Helianthus annuus L.), bunga kertas (Zinnia sp) dan Kenikir (Cosmos caudatus). Jenis tanaman refugia tersebut seperti terlihat pada Gambar 1.

Selain terdapat beberapa jenis hama utama pada tanaman kedelai dengan gejala serangan daun berlubanglubang yang disebabkan oleh penggerek daun ada pula musuh alami yang berada di tanaman refugia, seperti kumbang kubah, kupu-kupu, belalang sembah (Gambar 2). Hal ini sudah menunjukkan bahwa terdapat pemulihan kondisi linngkungan dan terjadi keseimbangan ekosistem untuk pertumbuhan dan peningkatan hasil. Aplikasi yang dilakukan adalah membuat desain rekayasa ekologi, yaitu desain sebuah sistem pertanian berkelanjutan dengan menanam tanaman refugia di sekitar areal tanaman yang dibudidayakan (Kangas, 2005).

Dari hasil tersebut masih ditemukan ulat penggerek daun dan juga beberapa daun kedelai yang dihinggapi oleh kutu aphid. Keberadaan aphid juga dapat merupakan vektor virus yang menyerang tanaman kedelai. Hal ini menyebabkan laju pertumbuhan menurun dan pembentukan polong terganggu. Polong yang dihasilkan dari beberapa tanaman tidak berisi karena serangan kutu aphid dan virus yang menyerang daun. Hal ini sejalan dengan pendapat Rutledge, et al., (2004) yang menyatakan bahwa serangan virus menurunkan vigoritas tanaman dan sekaligus menurunkan hasil.

Selama proses penyuluhan, diskusi berkembang mulai dari penyakit dan hama secara umum pada tanaman hortikultura kemudian secara khusus pada tanaman kedelai dan cara pengendaliannya. Intinya petani sangat antusias mengikuti penyuluhan yang dilakukan oleh tim penyuluh terlihat dari jumlah kehadiran para petani dan diskusi sangat hidup dan berkembang kemudian pertemuan diakhiri dengan foto bersama antara para petani dan tim penyuluh (Gambar 3).

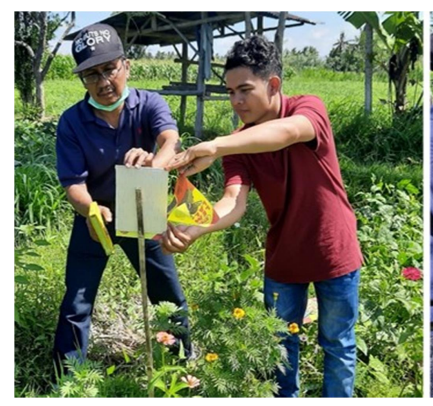

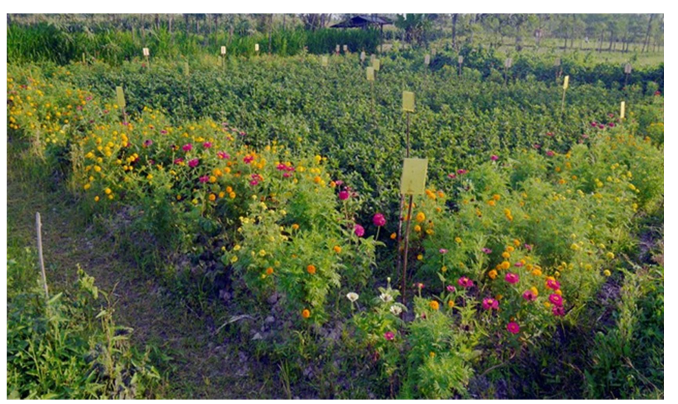

Gambar 1

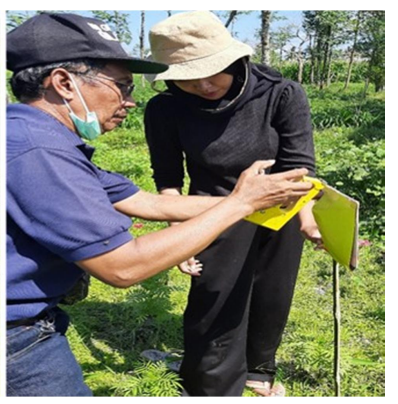

tuk memonitor jenis serangan di areal Demplot (kiri) dan Keadaan Demplot dengan tanaman refugia di sekelilingnya (kanan) 

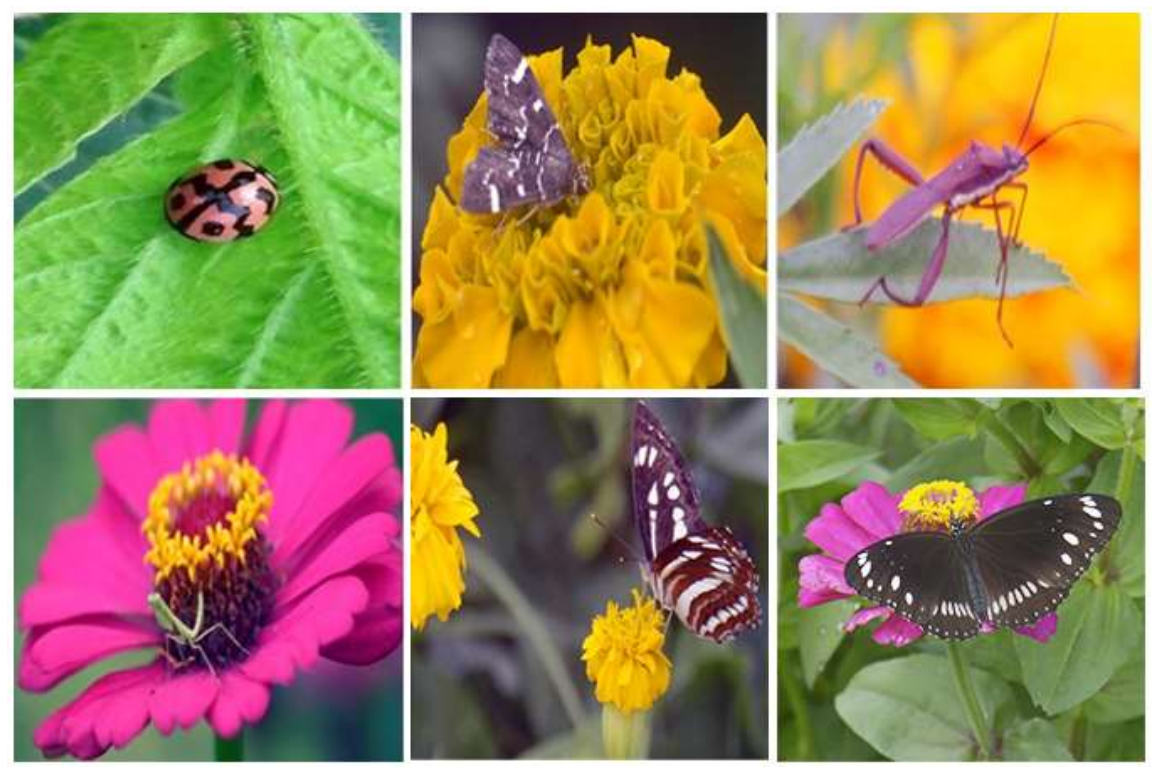

Gambar 2.

Beberapa musuh alami hinggap pada bunga dari tanaman refugia, seperti kepik, kumbang kubah, kupu-kupu, belalang sembah.
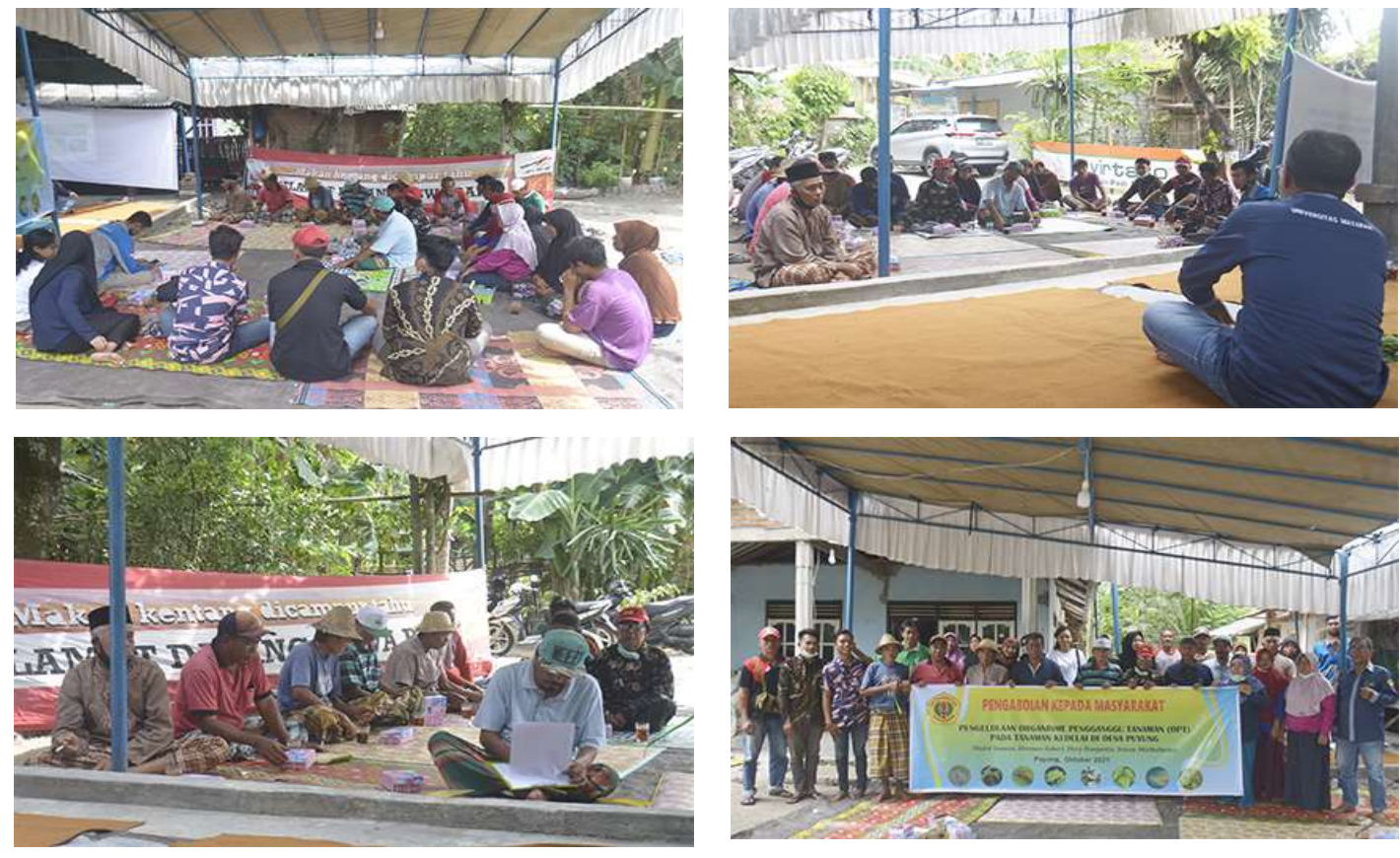

Gambar 3.

Peserta dari kelompok tani yang terlihat antusias mendengarkan penyuluhan yang dilakukan oleh tim penyuluh dari Fakultas Pertanian Unram.

\section{KESIMPULAN DAN SARAN}

Dapat disimpulkan bahwa kegiatan Pengabdian Kepada Masyarakat yang dikemas dalam bentuk Petak Demonstrasi telah berlangsung dengan baik. Dari kegiatan pengabdian kepada masyarakat ini dapat disimpulkan bahwa kelompok tani berkeinginan untuk menerapkan tanaman refugia sebagai perangkap musuh alami hama pada tanaman palawija khususnya kedelai. Untuk menunjang keinginan tersebut, tim penyuluh mempersiapkan pedoman berupa brosur tentang teknik pengendalian hama dengan memanfaatkan tanaman refugia sebagai tanaman perangkap musuh alami hama. 
Disarankan kepada kelompok tani untuk membantu dalam penyebaran teknologi tersebut kepada petani lain di sekitarnya, agar tercipta lingkungan secara luas yang lebih kondusif bagi berkembangnya musuh alami hama.

\section{Ucapan Terima Kasih}

Penulis mengucapkan terima kasih kepada Universitas Mataram yang sudah menyediakan dana melalui anggaran PNBP 2021 untuk pelaksanaan kegiatan Pengabdian Kepada Masyarakat (PkM) ini. Terima kasih yang sebesar-besarnya juga disampaikan kepada Kelompok Tani Bunut Serempek, Dusun Bangket Tengak, Desa Puyung, Kecamatan Jonggat, Lombok Tengah yang sudah bersedia menjadi mitra dalam pelaksanaan kegiatan PkM dan berkomitmen untuk menerapkan teknologi budidaya yang dihasilkan dari pelaksanaan PkM tersebut.

\section{Daftar Pustaka}

Anggoro, S. 2014. (www.dinpertan.grobogan.go.id/komoditas-126-rekayasa-ekologi-untuk-pertanian-berwawasanlingkungan-dan berkelanjutan.html). Diakses pada 20 Maret 2018.

Bohlool, B. B., Ladha, J. K., Garrity, D., dan George, T. 1992. Biological nitrogen fixation for sustainable agriculture: A perspective. Plant and Soil, 141, 1-11.

Byrnes, B. H. 1990. Environmental effects of N fertilizer use-an overview. Fertilizer Research, 26, 209-21.

Kangas, P. C. 2005. Ecological Engineering : Principles and Practice. Lewis Publishers.

Mahmud, T. 2006. Identifikasi Serangga di sekitar Tumbuhan Kangkungan (Ipomoea crassicaulis Roob). Skripsi. Universitas Islam Negeri Malang.

Rutledge, C. E., O’Niel, R. J., Fox, T. B, Landis, D. A. 2004. Soybean aphid predators and their use in IPM. Ann. Entomol. Soc. Am. 97:240-248.

Zhu, Z. L. dan Chen, D. L. 2002. Nitrogen fertilizer use in China - Contributions to food production, impacts on the environment and best management strategies. Nutrient Cycling in Agroecosystems, 63, 117-127. 